\title{
Efficacy of removing Candida albicans from orthodontic acrylic bases: an in vitro study
}

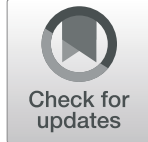

Abdul Razzak A. Ghazal ${ }^{*}$ D , Ghassan Idris², Mohammad Y. Hajeer ${ }^{3}$, Karam Alawer ${ }^{4}$ and Richard D. Cannon²

\begin{abstract}
Background: This study evaluated the efficacy of four methods in removing Candida albicans from the acrylic base material used to fabricate removable orthodontic appliances.

Methods: Heat-processed bars of orthodontic acrylic were incubated in a suspension of C. albicans for $2 \mathrm{~h}$ at $37^{\circ} \mathrm{C}$. Samples were allocated into five groups (five bars per group) according to the cleaning method: (1) manual brushing using a toothbrush; (2) soaking in a commercial denture cleaning solution; (3) soaking in a commercial mouthwash solution; (4) using an ultrasonic cleaner; and (5) soaking in distilled water as a negative control. Yeast remaining attached to the bars after cleaning were removed by vortexing in growth medium and plated on Sabouraud dextrose agar. The reduction in yeast colony count after cleaning was calculated and expressed as the number of colony forming units per acrylic bar (CFU/bar). The experiment was carried out three times.

Results: All four cleaning methods resulted in a significant decrease in viable yeast cells associated with the acrylic bars compared to the control group. The mean percentage reduction in viable yeast cells affected by the cleaning methods was: brushing 89.9\%; chlorhexidine 95.8\%; ultrasonic cleaning 99.9\%; and denture tablet 100\%.

Conclusions: All four methods evaluated in this study were effective, to some extent, in removing C. albicans from orthodontic acrylic samples. The most effective, and readily available, cleaning method was the use of commercial denture sterilizing tablets.
\end{abstract}

Keywords: Candida albicans, Orthodontic acrylic, Orthodontic appliances, Disinfection

\section{Background}

Candida albicans is considered one of the normal components of the oral flora as more than $60 \%$ of healthy populations are colonized by this yeast without clinical symptoms of infection [1]. C. albicans, which is the most frequently isolated species of Candida [2], could pose a serious clinical challenge in immune-compromised individuals (people with HIV infection, xerostomia, diabetes, leukemia etc.) [3-5]. There is an increasing number of children surviving cancer who, just like their healthy peers, seek orthodontic treatment [6]. This is a special group of patients that should be particularly motivated to maintain dental hygiene $[6,7]$, because the reduction in immune function allows $C$. albicans to proliferate and to cause infection $[8,9]$. Similarly, children whose saliva

\footnotetext{
* Correspondence: dr-ghazal@hotmail.com

${ }^{1}$ Technical Institution of Dentistry, University of Hama, Hama, Syria Full list of author information is available at the end of the article
}

contains reduced amounts of antimicrobial proteins have less protection from candidiasis [10].

Removable orthodontic appliances are a popular tool to move, or retain, teeth during, or after, orthodontic treatment $[11,12]$. Nocturnal wearing of the acrylic removable orthodontic appliances may play a role in the development of oral C. albicans infections. This could be due to low salivary flow and consequently low $\mathrm{pH}$ levels as well as impaired oral hygiene $[8,13,14]$. Wearing acrylic orthodontic appliances has been reported to be associated with increased proliferation of Candida regardless of the host immune system status [2, 11-13]. These appliances provide an enhanced environment for C. albicans growth as they cover a large area of mucosal tissues for a considerable amount of time every day for a relatively long period $[15,16]$. The removable appliances protect the yeast from the natural flow of saliva and mechanical removal effects of musculature. The orthodontic acrylic also provides a hydrophobic surface to

(c) The Author(s). 2019 Open Access This article is distributed under the terms of the Creative Commons Attribution 4.0 International License (http://creativecommons.org/licenses/by/4.0/), which permits unrestricted use, distribution, and reproduction in any medium, provided you give appropriate credit to the original author(s) and the source, provide a link to the Creative Commons license, and indicate if changes were made. The Creative Commons Public Domain Dedication waiver (http://creativecommons.org/publicdomain/zero/1.0/) applies to the data made available in this article, unless otherwise stated. 
which C. albicans can bind through the hydrophobic effect and van der Waals forces. [14]. The combination of these factors may tip the balance in the wearers of orthodontic appliances to support Candida colonization and proliferation $[2,8]$ and also increase dentine demineralization by enhancing the cariogenic potential of Streptococcus mutans containing biofilms [17].

Although the increased colonization of individuals wearing removable dentures and removable orthodontic appliances by $C$. albicans might be expected to be similar [18], the two types of acrylic resin have different physical properties, and different fabrication and polymerization methods that affect the amount of residual monomer, which might affect the surface morphology and C. albicans adhesion [12, 19, 20].

Several in vitro studies have shown that different cleaning methods remove $C$. albicans from acrylic removable dentures to different extents. These studies have compared the efficiency of using chemical and mechanical methods of removing $C$. albicans from acrylic denture base resin [21-23], but there is no published data evaluating the procedures used in cleaning removable acrylic orthodontic appliances. The aim of this research was to assess the effectiveness of brushing with a toothbrush, soaking in a solution of a commercial denture cleaner, immersing in chlorhexidine gluconate oral rinse solution and using an ultrasonic cleaning to remove C. albicans from orthodontic acrylic resin.

\section{Methods}

\section{Fabrication of orthodontic acrylic samples}

Seventy-five identical acrylic bars with a surface topology of clinical relevance were fabricated using duplicated dental stone casts of an 11 year-old orthodontic patient. An alginate impression (Hydrogum ${ }^{\circ}$, Zhermack, Badia Polesine, Italy) of the upper dental arch of the patient was taken as part of routine orthodontic treatment, and a cast made using yellow dental stone (Maarc ${ }^{\mathrm{Tm}}$, Mumbai, India).
In order to fabricate identical acrylic bars, the following procedure was applied to the cast. A rectangular sulcus $(12 \times 25 \times 2 \mathrm{~mm})$ was carved in the palate portion of the dental cast (Fig. 1) and the modified cast was copied using silicon duplication material: Silicopy, SPD, Mulazzano, Italy.

Using this silicon mold, 75 yellow stone casts were poured (in three groups of 25 casts). To fabricate the acrylic bars, the spray-on (salt and pepper) method was used to fill in the marked rectangular area in each cast using an orthodontic heat-polymerized acrylic resin (Dentaurum Orthocryl ${ }^{\circ}$, Ispringen, Deutschland). The dimensions of the bars were confirmed using a Boley Gauge Caliper. The heat-polymerization process was used for all the samples according to manufacturer's instructions. The acrylic bars were finished and polished on only one side to simulate the fabrication of removable orthodontic appliances (Fig. 1).

\section{Isolation and identification of Candida albicans}

Fresh C. albicans clinical isolates were obtained by sampling the palatal surface of a patient's removable orthodontic appliance with a sterile swab, plating on Sabouraud dextrose agar with chloramphenicol (HiMedia ${ }^{\circ}$ Mumbai, India) and incubating at $37^{\circ} \mathrm{C}$ for $48 \mathrm{~h}$.

Isolates were confirmed as C. albicans by the germ tube test and chlamydospore formation as described previously $[14,24]$.

\section{Coating acrylic bars with human saliva}

Acrylic bars were coated with human saliva to mimic the in vivo condition for orthodontic appliances. Unstimulated saliva $(10 \mathrm{~mL})$ was collected from each of 12 healthy adults ( 6 males and 6 females), mixed and centrifuged at $5000 \times \mathrm{g}$ for $10 \mathrm{~min}$ at $4{ }^{\circ} \mathrm{C}$ [25]. The saliva supernatant was immediately stored at $-70^{\circ} \mathrm{C}$ until use.
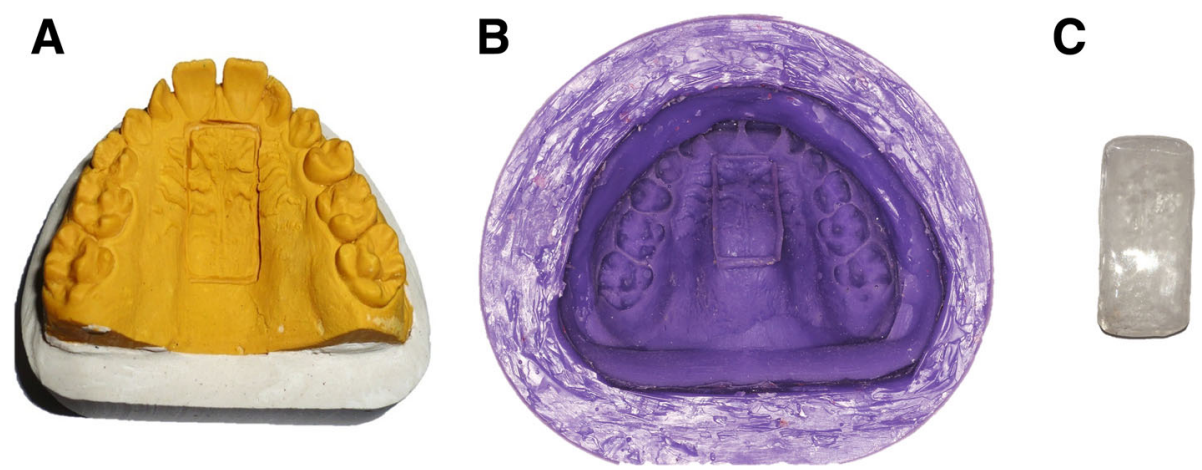

Fig. 1 Fabrication of orthodontic acrylic bars: a Dental cast with $12 \times 25 \times 2 \mathrm{~mm}$ rectangular sulcus carved in the palate, b The silicon mold used to fabricate stone models and $\mathbf{c}$ One of the acrylic bars 


\section{Ethical approval and consent forms}

Following approval of the study by the University of Hama Local Ethics Committee, and providing verbal and written explanation of the intended research, consent forms were signed by the parents of the patient whose orthodontic impression was used and by those who provided unstimulated saliva samples.

\section{Preparation of $C$. albicans to coat acrylic}

The C. albicans clinical isolate was cultured on Sabouraud dextrose agar with chloramphenicol (HiMedia ${ }^{\circ}$ ) at $37^{\circ} \mathrm{C}$ for $48 \mathrm{~h}$. A yeast suspension was prepared by harvesting $C$. albicans cells and adjusting the concentration with dual distilled water to $10^{7} \mathrm{CFU} / \mathrm{mL}$ (colony forming unit $/ \mathrm{mL}$ ) by comparing it with the optical density of a McFarland standard [22, 23].

\section{Attachment of C. albicans to acrylic bars}

The acrylic bars were disinfected by immersing them in alcohol $70 \% \mathrm{v} / \mathrm{v}$ (volume per volume) for $10 \mathrm{~min}$ and then washing them in ultrapure water for $1 \mathrm{~min}$. Next, bars were individually exposed to $2 \mathrm{ml}$ of the previously prepared human saliva in test tubes at room temperature for $30 \mathrm{~min}[26,27]$ and washed in ultrapure water for 1 min. Each acrylic bar was then placed in a test tube containing $8 \mathrm{~mL}$ of the $C$. albicans suspension and placed in an incubator at $37^{\circ} \mathrm{C}$.
After $2 \mathrm{~h}$ incubation, each sample was removed using sterile tongs, washed with $5 \mathrm{~mL}$ of ultrapure water (Fig. 2).

\section{Cleaning of specimens}

All disinfection assays were performed on groups of five acrylic bars $(n=5)$. The assays were carried out on three separate occasions with freshly grown $C$. albicans cells. The following procedures were applied to the groups of five bars (Fig. 2).

The Brushing group (Group 1) samples were brushed manually using a medium-bristle toothbrush (123 Classic Care, Oral- $\mathrm{B}^{\oplus}$, UK) on all sides under running sterilized water for $1 \mathrm{~min}$. A new toothbrush was used for each bar.

The Tablets group (Group 2) samples were immersed in $200 \mathrm{~mL}$ of ultrapure water in which one tablet of commercial denture cleaner (Corega ${ }^{\circ}$ tabs - GlaxoSmithKline, Ireland, UK) had been dissolved, for $15 \mathrm{~min}$ at room temperature. According to the manufacturer, the tablets contained: sodium bicarbonate, citric acid, potassium monopersulfate, sodium carbonate, sodium carbonate peroxide, tetra-acetyl ethylene diamine, sodium benzoate, PEG-180, sodium lauryl sulfoacetate, PVP/VA copolymer, aroma, subtilisin, sodium nitrite, CI 42090 (Brilliant Blue colorant) and CI 73015 (Indigo carmine colorant).

The Chlorhexidine group (Group 3) samples were immersed in $200 \mathrm{~mL}$ of $0.12 \%$ of chlorhexidine

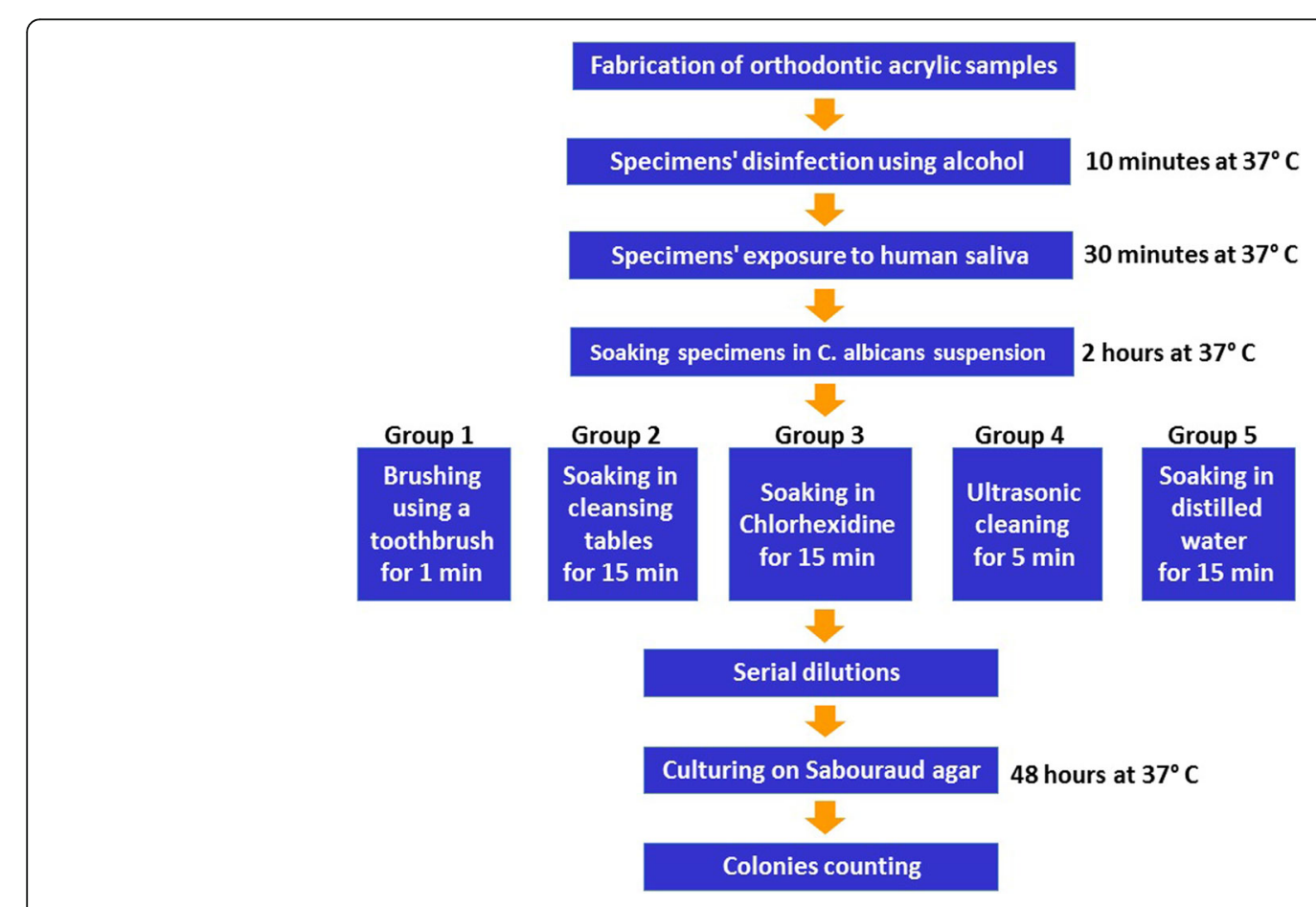

Fig. 2 Flow chart of the method employed in the study 
gluconate (Peridex ${ }^{\mathrm{m}}: 3 \mathrm{M}, \mathrm{MN}$, USA) for $15 \mathrm{~min}$ at room temperature .

The Ultrasonic cleansing group (Group 4), samples were cleaned using an ultrasonic cleaner (CD-4820, GS, China) at a frequency of $50 \mathrm{~Hz}$ and power of $170 \mathrm{~W}$ for 5 min.

The last group was the control group (Group 5) and samples were immersed in $200 \mathrm{~mL}$ of ultrapure water for 15 min.

\section{Assessment of efficacy of the cleaning methods}

Subsequent to the cleaning treatment, samples were placed in $1 \mathrm{~mL}$ of Sabouraud dextrose with chloramphenicol broth and vortexed for $2 \mathrm{~min}$. Tenfold serial dilutions of each sample were prepared from $10^{1}$ to $10^{5}$, then $100 \mu \mathrm{L}$ from each dilution was spread on a Sabouraud dextrose agar plate. The agar plates were incubated at $37^{\circ} \mathrm{C}$ for $48 \mathrm{~h}$. The C. albicans colonies on the agar plates were counted manually (the total number of viable $C$. albicans cells $=$ the number of colonies $\mathrm{x}$ the dilution factor $\times 10$ ) and expressed in number of colony forming units per millilitre $(\mathrm{CFU} / \mathrm{mL})$ which is equivalent to the CFU/bar (Table 1). The percentage reduction due to the cleaning was calculated using the following formula: persentage reduction $=\left(\mathrm{CFU} / \mathrm{bar}_{\mathrm{c}}-\mathrm{CFU} / \mathrm{bar}_{\mathrm{t}}\right)$ $\div \mathrm{CFU} / \mathrm{bar}_{\mathrm{c}} \times 100$ where CFU/bar ${ }_{\mathrm{c}}=\mathrm{CFU} / \mathrm{bar}$ with no treatment (control) and $\mathrm{CFU} / \mathrm{bar}_{\mathrm{t}}=\mathrm{CFU} / \mathrm{bar}$ after treatment.

\section{Statistical analysis}

Since the data of all groups were normally distributed (Anderson-Darling test), parametric tests were used. Because the experiment was conducted three times, repeated measures analysis of variance (rANOVA) was used to assess any discrepancy in the results obtained in the three replicates of each method. With alpha set at $5 \%$, one-way analysis of variance (ANOVA) was used to detect differences in the $\mathrm{CFU} / \mathrm{ml}$ counts between the five groups. This was followed by least significant difference (LSD) post hoc pairwise comparisons. All analyses were conducted using SPSS software (SPSS, IBM Corp. Version 22.0. Armonk, NY, USA).

\section{Results}

The C. albicans clinical isolate adhered well to the saliva-coated orthodontic acrylic bars, with an average of 9133 cells recovered from the bars by vortexing in growth medium. All cleaning methods reduced the number of $C$. albicans CFU adhered to the bars (Table 1). Repeated measures ANOVA showed no significant differences between the three replicates in Brushing group $(P=.850)$, Tablets group (equal values), Chlorhexidine $(P=.416)$, Ultrasonic group $(P=.605)$ or Control group $(P=.371)$.

The different cleaning methods reduced the number of C. albicans CFU adhering to orthodontic acrylic bars to differing extents. The order of efficacy of removing $C$. albicans CFU was: Tablets $>$ Ultrasonic cleansing $>$ Chlorhexidine $>$ Brushing. There were no detectable viable $C$. albicans cells associated with the acrylic bars after treatment with denture Tablets. Regarding the differences observed between the five groups, LSD post-hoc tests showed that there was a significant difference between the control group compared to the other groups (Table 1) $(P<0.001)$. Pairwise comparisons of brushing, tablets, chlorhexidine and ultrasonic groups showed no significant difference between cleaning methods (Table 1).

\section{Discussion}

Acrylic resin plates are widely used as removable orthodontic appliances and it is important to understand the effect of wearing orthodontic appliances on intraoral colonization by bacteria and fungi. Removable orthodontic appliances are important tools in the orthodontist's armamentarium and they are commonly use in treating a range of malocclusions. The use of such appliances has been shown to inhibit oral hygiene occlude surfaces and enhance the proliferation of microorganisms [11, 28].

C. albicans is considered a significant opportunistic pathogen due to its ability to adhere to a variety of surfaces, generate drug-resistant biofilms, and secrete proteinases and a toxin [29]. These numerous virulence factors mean that if it's growth is not kept in check it can become pathogenic both locally and systemically leading to various forms of candidiasis [29, 30]. The

Table 1 Effect of different cleaning methods in the removal of C. albicans from acrylic bars

\begin{tabular}{|c|c|c|c|c|c|}
\hline \multirow{2}{*}{$\begin{array}{l}\text { Treatment } \\
\text { method }\end{array}$} & \multicolumn{2}{|l|}{ CFU/bar, mean \pm SD (range) $n=3$} & \multirow[t]{2}{*}{ Reduction \% } & \multicolumn{2}{|l|}{ Statistical analysis, $P$ values } \\
\hline & CFU/bar with no treatment (Control) & CFU/bar after treatment & & Comparison with control & Inter-treatment comparison \\
\hline Brushing & $9133 \pm 3282(4300-15,100)$ & $918.7 \pm 267.7(620-1420)$ & 89.9 & $<0.01$ & $\begin{array}{l}\text { To Tablet }>0.05(0.092) \\
\text { To CHX >0.05 }(0.323) \\
\text { To US }>0.05(0.095)\end{array}$ \\
\hline Tablets & & $0 \pm 0(0-0)$ & 100 & $<0.01$ & $\begin{array}{l}\text { To CHX > } 0.05(0.479) \\
\text { To US > } 0.05(0.990)\end{array}$ \\
\hline $\mathrm{CHX}$ & & $382.7 \pm 131.1(180-620)$ & 95.8 & $<0.01$ & To US > 0.05 (0.487) \\
\hline US & & $6.67 \pm 11.13(0-30)$ & 99.9 & $<0.01$ & N/A \\
\hline
\end{tabular}

CHX chlorhexidine, US ultrasonic cleaner 
importance of keeping removable orthodontic appliances appliances Candida-free has been emphasised in several reports $[11,13,15]$, however, this study is the first to compare the effectiveness of different methods of removing $C$. albicans cells from these widely used appliances.

This study used clinically relevant replicates of orthodontic acrylic bars reproducibly coated with a relatively large number of $C$. albicans cells. The cells probably adhered to the micro-indentations on the internal non-polished surface of the acrylic as with dental acrylic [31]. The porosity and water-absorbing ability of heat-cured acrylic makes an amenable environment for C. albicans colonization and growth [32].

Brushing with a toothbrush, which is considered the most common method of controlling plaque development on acrylic surfaces [33], removed $89.9 \%$ of C. albicans cells. A similar finding was reported by Pellizzaro et al. [34] who obtained a 96\% reduction of Candida biofilm. Other studies have shown that brushing was an ineffective method for Candida removal [35, 36]. Contrary to the findings presented here, a study comparing mechanical brushing to chemical methods found that a toothbrush is more effective than some chemical methods when using cleaning tablet. [37]. This difference could be explained by the use of dentifrice with the toothbrush in the study by Paranhos et al. [37] and soaking samples in tablets for a shorter time (i.e., $5 \mathrm{~min}$ ). It is possible that the toothbrush is unable to dislodge cells within the pores of the fitting surface of the acrylic bars.

Soaking acrylic samples in chlorhexidine $0.12 \%$ caused a significant $95.8 \%$ reduction in viable cells associated with the acrylic bars. This is due to the fact that chlorhexidine is able to increase C. albicans cell permeability allowing the chlorhexidine gluconate to enter the cell [38], leading to cell wall damage and cell death [39]. Immersing acrylic appliances in chlorhexidine for a relatively short time mimics the real life use of mouthwashes which have been shown to be effective against Candida [38, 40-42]. Mouthrinses have an extra advantage of their pleasant odor [40] that might encourage routine disinfection of removable orthodontic appliances.

Ultrasonic cleaning of the acrylic bars was an effective method that removed more than $99.9 \%$ of C. albicans cells. Kawasaki et al. [31], however, reported that more than $11 \%$ of Candida cells remained following $15 \mathrm{~min}$ of ultrasonic cleaning (even though the maximum removal was achieved in the first $5 \mathrm{~min}$ ). The reduced effectiveness of ultrasonic cleaning in that study could be due to the different acrylic base resin, C. albicans strain and ultrasonic cleaner used. Muscat et al. suggested the use of an ultrasonic treatment for only $30 \mathrm{~s}$ as being an effective method for removing $C$. albicans, but the acrylic samples were made of self-cure poly methyl methacrylate
(PMMA). Although effective in the present study, it is unlikely that ultrasonic cleaners will be widely used by orthodontic patients for cleaning their removable appliances.

Soaking the orthodontic acrylic bars in a commercial denture cleaning solution (dissolved tablets) resulted in no viable $C$. albicans cells associated with the bars. Many researchers [23, 34, 40] have used effervescent tablets to clean acrylic dentures since they are promoted as acrylic-friendly products even when used for prolonged periods [43]. The mechanism of cleansing acrylic resin with tablets starts once the tablet dissolves in water, as an alkaline peroxide solution is formed. This solution then releases oxygen bubbles enabling a mechanical cleaning [23] in addition to chemical cleaning enhanced by sodium lauryl sulfoacetate, a detergent that penetrates through the cell wall and permeabilises the cell membrane causing leakage of intracellular components and cell lysis $[34,44]$. These multiple mechanisms may be responsible for eliminating all viable $C$. albicans from orthodontic acrylic specimens in the current study.

Montagner et al. reported that cleansing tablets were ineffective when soaking acrylic samples for only $5 \mathrm{~min}$ [45] while Yildirim-Bicer et al. [23] found that $0.1 \%$ of Candida cells survived after $10 \mathrm{~min}$ soaking. However, in the current study the acrylic bars were soaked for 15 min, this additional soaking time could have increased the efficacy of sample disinfection. Iseri et al. [40] found that tablets could not completely eliminate Candida from denture base acrylic resin even after 60 min disinfection. However, this study used tablets with a different chemical composition that did not contain sodium lauryl sulfoacetate which may be the efficacious component for C. albicans elimination. [34]. It should be noted that in the current in vitro study, orthodontic acrylic bars were coated with only C. albicans - without any other microorganisms. In the oral cavity, C. albicans will be incorporated into poly-microbial communities on orthodontic acrylic appliances leading to a complex interaction that could modulate Candida adherence and reduce the efficacy of the cleansing methods evaluated in the current study [46].

\section{Conclusions}

This study showed that brushing, the denture cleaning tablets, chlorhexidine gluconate and ultrasonic cleaning can remove $C$. albicans from the surface of orthodontic acrylic. Although no significant difference was found between the test methods, commercially available denture cleaning tablets proved to be the most effective method.

\footnotetext{
Abbreviations

C. albicans: Candida albicans; CFU: Colony forming unit; CHX: Chlorhexidine; LSD: Least significant difference; PMMA: Poly methyl methacrylate; rANOVA: Repeated measures analysis of variance; US: Ultrasonic; v/v: Volume per volume; $\mu \mathrm{L}$ : Microliter
} 


\section{Acknowledgements}

The authors would like to acknowledge Dr. Ghassan Alhilali, Research microbiology Laboratory, Hama University, Hama, Syria for his professional assisstance.

\section{Funding}

We would like to thank the team of the Research Microbiology Laboratory, Hama University, Hama, Syria for the facilities and professional assistance provided.

\section{Availability of data and materials}

The datasets used and/or analyzed during the current study are available from the corresponding author on reasonable request.

\section{Authors' contributions}

ARAG conceived of the study, carried out the samples' fabrication, participated in the sequence experiments, and drafted the manuscript. Gl participated in the study coordination and helped to draft and revise the written work. MYH performed the statistical analysis and helped to revise the written work. KA carried out the isolation and identification of Candida albicans and the sequence laboratory procedures. RDC was the research supervisor and helped to revise the written work. All authors read and approved the final manuscript.

\section{Ethics approval and consent to participate}

This study was approved by the University of Hama Local Ethics Committee (TID-21-16), and informed consent was obtained from the parents of the patient whose orthodontic impression was used and from those who gave unstimulated saliva samples.

\section{Consent for publication}

Not applicable.

\section{Competing interests}

The authors declare that they have no competing interests.

\section{Publisher's Note}

Springer Nature remains neutral with regard to jurisdictional claims in published maps and institutional affiliations.

\section{Author details}

${ }^{1}$ Technical Institution of Dentistry, University of Hama, Hama, Syria. ${ }^{2}$ Sir John Walsh Research Institute, University of Otago, Dunedin, New Zealand. ${ }^{3}$ Department of Orthodontics, University of Damascus Dental School, Damascus, Syria. ${ }^{4}$ Research microbiology Laboratory, Hama University, Hama, Syria.

\section{Received: 9 May 2018 Accepted: 15 April 2019}

Published online: 02 May 2019

\section{References}

1. Grimoud AM, Marty N, Bocquet H, Andrieu S, Lodter JP, Chabanon G. Colonization of the oral cavity by Candida species: risk factors in long-term geriatric care. J Oral Sci. 2003:45(1):51-5.

2. Farronato G, Giannini L, Galbiati G, Cannalire P, Martinelli G, Tubertini I, Maspero C. Oral tissues and orthodontic treatment: common side effects. Minerva Stomatol. 2013;62(11-12):431-46.

3. Parvinen T, Larmas $\mathrm{M}$. The relation of stimulated salivary flow rate and $\mathrm{pH}$ to Lactobacillus and yeast concentrations in saliva. J Dent Res. 1981;60(12): 1929-35.

4. Karjalainen KM, Knuuttila ML, Kaar ML. Salivary factors in children and adolescents with insulin-dependent diabetes mellitus. Pediatr Dent. 1996; 18(4):306-11.

5. Lin AL, Johnson DA, Patterson TF, Wu Y, Lu DL, Shi Q, Yeh CK. Salivary anticandidal activity and saliva composition in an HIV-infected cohort. Oral Microbiol Immunol. 2001;16(5):270-8.

6. Mituś-Kenig M, Łoboda M, Marcinkowska-Mituś A, Durka-Zajac M, Pawłowska E. Orthodontic treatment in oncological patients. Przegl Lek. 2015;72(5):243-5.

7. Neill CC, Migliorati C, Trojan T, Kaste S, Karydis A, Rowland C, Parris W. Experience and expertise regarding orthodontic management of childhood and adolescent cancer survivors. Am J Orthod Dentofac Orthop. 2015; 148(5):765-70.

8. Hibino K, Samaranayake LP, Hagg U, Wong RW, Lee W. The role of salivary factors in persistent oral carriage of Candida in humans. Arch Oral Biol. 2009;54(7):678-83.

9. Niimi M, Firth NA, Cannon RD. Antifungal drug resistance of oral fungi. Odontology. 2010;98(1):15-25.

10. Edgerton M, Koshlukova SE, Lo TE, Chrzan BG, Straubinger RM, Raj PA. Candidacidal activity of salivary histatins. Identification of a histatin 5binding protein on Candida albicans. J Biol Chem. 1998;273(32):20438-47.

11. Kundu R, Tripathi AM, Jaiswal JN, Ghoshal U, Palit M, Khanduja S. Effect of fixed space maintainers and removable appliances on oral microflora in children: an in vivo study. J Indian Soc Pedod Prev Dent. 2016;34(1):3-9.

12. Hibino K, Wong RW, Hagg U, Samaranayake LP. The effects of orthodontic appliances on Candida in the human mouth. Int J Paediatr Dent. 2009;19(5): 301-8.

13. Arendorf T, Addy M. Candidal carriage and plaque distribution before, during and after removable orthodontic appliance therapy. J Clin Periodontol. 1985;12(5):360-8.

14. Webb B, Thomas C, Willcox M, Harty D, Knox K. Candida-associated denture stomatitis. Aetiology and management: a review: Part1. Factors influencing distribution of candida species in the oral cavity. Aust Dent J. 1998;43(1):45-50

15. G Gong SQ, Epasinghe J, Rueggeberg FA, Niu LN, Mettenberg D, Yiu CK, Blizzard JD, Wu CD, Mao J, Drisko CL, et al. An ORMOSIL-containing orthodontic acrylic resin with concomitant improvements in antimicrobial and fracture toughness properties. PLoS One. 2012;7(8):e42355.

16. Tsomos G, Ludwig B, Grossen J, Pazera P, Gkantidis N. Objective assessment of patient compliance with removable orthodontic appliances: a crosssectional cohort study. Angle Orthod. 2014;84(1):56-61.

17. Sampaio AA, Souza SE, Ricomini-Filho AP, Del Bel Cury AA, Cavalcanti YW, Cury JA. Candida albicans increases dentine demineralization provoked by Streptococcus mutans biofilm. Caries Res. 2018;53(3):322-31.

18. Yitschaky O, Katorza A, Zini A, Yitschaky M, Zadik Y. Acrylic orthodontic retainer is not a risk factor for focal Candida colonization in young healthy patients: a pilot study. Oral Surg Oral Med Oral Pathol Oral Radiol. 2016; 121(1):39-42.

19. Aslanimehr M, Rezvani S, Mahmoudi A, Moosavi N. Comparison of Candida Albicans adherence to conventional acrylic denture base materials and injection molding acrylic materials. J Dent (Shiraz). 2017;18(1):61-4.

20. Ica RB, Ozturk F, Ates B, Malkoc MA, Kelestemur U. Level of residual monomer released from orthodontic acrylic materials. Angle Orthod. 2014 84(5):862-7.

21. Srinivasan M, Gulabani M. A microbiological evaluation of the use of denture cleansers in combination with an oral rinse in complete denture patients. Indian J Dent Res. 2010;21(3):353.

22. Lee $\mathrm{H}-\mathrm{E}$, Li C-Y, Chang H-W, Yang $\mathrm{Y}-\mathrm{H}$, Wu J-H. Effects of different denture cleaning methods to remove Candida albicans from acrylic resin denture based material. J Dent Sci. 2011:6(4):216-20.

23. Yildirim-Bicer AZ, Peker I, Akca G, Celik I. In vitro antifungal evaluation of seven different disinfectants on acrylic resins. Biomed Res Int. 2014;2014: 519098

24. Sandven P. Laboratory identification and sensitivity testing of yeast isolates. Acta Odontol Scand. 1990;48(1):27-36.

25. Lazarin AA, Machado AL, Zamperini CA, Wady AF, Spolidorio DMP, Vergani CE. Effect of experimental photopolymerized coatings on the hydrophobicity of a denture base acrylic resin and on Candida albicans adhesion. Arch Oral Biol. 2013;58(1):1-9.

26. Izumida FE, Moffa EB, Vergani CE, Machado AL, Jorge JH, Giampaolo ET. In vitro evaluation of adherence of Candida albicans, Candida glabrata, and Streptococcus mutans to an acrylic resin modified by experimental coatings. Biofouling. 2014;30(5):525-33.

27. Zamperini CA, Schiavinato PC, Pavarina AC, Giampaolo ET, Vergani CE, Machado AL. Effect of human whole saliva on the in vitro adhesion of Candida albicans to a denture base acrylic resin: a focus on collection and preparation of saliva samples. J Investig Clin Dent. 2013;4(4):225-8.

28. Pithon MM, Santos RL, Alviano WS, Ruellas ACO, Araújo MTS. Quantitative assessment of $\mathrm{S}$. mutans and $\mathrm{C}$. albicans in patients with Haas and hyrax expanders. Dental Press J Orthod. 2012;17(3):1-6.

29. Garcia-Cuesta C, Sarrion-Perez MG, Bagan JV. Current treatment of oral candidiasis: a literature review. J Clin Exp Dent. 2014;6(5):e576-82. 
30. Inci M, Atalay MA, Koç AN, Yula E, Evirgen Ö, Durmaz S, Demir G. Investigating virulence factors of clinical Candida isolates in relation to atmospheric conditions and genotype. Turk J Med Sci. 2012;42(Sup. 2): 1476-83.

31. Kawasaki K, Kamikawa Y, Sugihara K. In vitro and in vivo removal of oral Candida from the denture base. Gerodontology. 2016;33(2):247-52.

32. Shimoyama K, Kurata S, Morishita K. Mechanical properties of resin material using various hydrophobic methacrylate monomers and cytotoxicity of hydrophobic methacrylate monomers on human pulp fibroblasts. Kanagawa Shigaku. 2003;38(1):9.

33. Paraskevas $S$, Rosema NA, Versteeg $P$, Timmerman MF, van der Velden $U$, van der Weijden GA. The additional effect of a dentifrice on the instant efficacy of toothbrushing: a crossover study. J Periodontol. 2007;78(6):1011-6.

34. Pellizzaro D, Polyzois G, Machado AL, Giampaolo ET, Sanita PV, Vergani CE. Effectiveness of mechanical brushing with different denture cleansing agents in reducing in vitro Candida albicans biofilm viability. Braz Dent J. 2012;23(5):547-54.

35. Webb BC, Thomas CJ, Whittle T. A 2-year study of Candida-associated denture stomatitis treatment in aged care subjects. Gerodontology. 2005; 22(3):168-76.

36. Shay K. Denture hygiene: a review and update. J Contemp Dent Pract. 2000; 1(2):28-41.

37. Paranhos HF, Silva-Lovato CH, de Souza RF, Cruz PC, de Freitas-Pontes KM, Watanabe $\mathrm{E}$, Ito IY. Effect of three methods for cleaning dentures on biofilms formed in vitro on acrylic resin. J Prosthodont. 2009;18(5):427-31.

38. Paulone S, Malavasi G, Ardizzoni A, Orsi CF, Peppoloni S, Neglia RG, Blasi E. Candida albicans survival, growth and biofilm formation are differently affected by mouthwashes: an in vitro study. New Microbiol. 2017:40(1):45-52.

39. MacNeill S, Rindler E, Walker A, Brown AR, Cobb CM. Effects of tetracycline hydrochloride and chlorhexidine gluconate on Candida albicans. J Clin Periodontol. 1997;24(10):753-60.

40. Iseri U, Uludamar A, Ozkan YK. Effectiveness of different cleaning agents on the adherence of Candida albicans to acrylic denture base resin. Gerodontology. 2011;28(4):271-6.

41. Fu J, Wei P, Zhao C, He C, Yan Z, Hua H. In vitro antifungal effect and inhibitory activity on biofilm formation of seven commercial mouthwashes. Oral Dis. 2014;20(8):815-20

42. Rahmani-Badi A, Sepehr S, Babaie-Naiej H. A combination of cis-2-decenoic acid and chlorhexidine removes dental plaque. Arch Oral Biol. 2015;60(11): 1655-61.

43. Budtz-Jorgensen E. Materials and methods for cleaning dentures. J Prosthet Dent. 1979:42(6):619-23.

44. Salton MR. Lytic agents, cell permeability, and monolayer penetrability. J Gen Physiol. 1968:52(1):227-52.

45. Montagner $\mathrm{H}$, Montagner F, Braun KO, Peres PEC. Gomes BPFdA: in vitro antifungal action of different substances over microwaved-cured acrylic resins. J Appl Oral Sci. 2009;17(5):432-5.

46. Thein ZM, Samaranayake YH, Samaranayake LP. Effect of oral bacteria on growth and survival of Candida albicans biofilms. Arch Oral Biol. 2006;51(8): $672-80$

Ready to submit your research? Choose BMC and benefit from:

- fast, convenient online submission

- thorough peer review by experienced researchers in your field

- rapid publication on acceptance

- support for research data, including large and complex data types

- gold Open Access which fosters wider collaboration and increased citations

- maximum visibility for your research: over $100 \mathrm{M}$ website views per year

At BMC, research is always in progress.

Learn more biomedcentral.com/submissions 